\title{
Reševanje problema inverzne kinematike s pomočjo algoritma diferencialne evolucije
}

\author{
Timi Kupčič \\ Univerze v Mariboru \\ Fakulteta za elektrotehniko, \\ računalništvo in informatiko \\ Koroška cesta 46 \\ 2000 Maribor \\ timi.kupcic@gmail.com
}

\author{
Janez Brest \\ Univerze v Mariboru \\ Fakulteta za elektrotehniko, \\ računalništvo in informatiko \\ Koroška cesta 46 \\ 2000 Maribor \\ janez.brest@um.si
}

\author{
Borko Bošković \\ Univerze v Mariboru \\ Fakulteta za elektrotehniko, \\ računalništvo in informatiko \\ Koroška cesta 46 \\ 2000 Maribor \\ borko.boskovic@um.si
}

\section{POVZETEK}

$\mathrm{V}$ članku predstavimo reševanje problema inverzne kinematike s pomočjo algoritma diferencialne evolucije. Algoritem preizkusimo na primeru robotske roke PUMA 560. Dobljeni rezultati so pokazali, da je algoritem relativno hiter in uspešen pri reševanju problema inverzne kinematike. Z velikostjo populacije 300 je algoritem dosegel $100 \%$ uspešnost za 10 naključno izbranih točk.

\section{Kjučne besede}

diferencialna evolucija, inverzna kinematika, robotska roka

\section{UVOD}

Inverzna kinematika predstavlja problem določanja parametrov sklepov roke, da le-to spravimo v željen položaj. Ta problem zasledimo na različnih področjih. Nekatera izmed teh področij obsegajo zabavno industrijo, kjer se je poslužujejo liki v računalniških igrah/animacijah, pa vse do robotskih rok, ki bodisi sodelujejo pri zapletenih operacijah v medicini ali pa zgolj opravljajo dela za tekočim trakom. Slednje prihaja vedno bolj v uporabo. S pomočjo podobnih rešitev, kot je naša, lahko roboti opravljajo vedno bolj zapletena in natančna opravila.

V članku bomo predstavili rešitev določanja parametrov robotske roke oz. položaja končnega člena s pomočjo algoritma diferencialne evolucije. V naslednjem poglavju bomo predstavili problem inverzne kinematike. $\mathrm{V}$ tretjem poglavju bomo podali opis algoritma diferencialne evolucije. Opis eksperimenta in dobljenih rezultatov podajamo v četrtem poglavju. Na koncu podajamo še kratek zaključek.

\section{PROBLEM INVERZNE KINEMATIKE}

Zamislimo si poljubno verigo, sestavljeno iz $n$ točk in $n-1$ poljubno dolgih povezav, ki te točke povezujejo. Ta veriga se

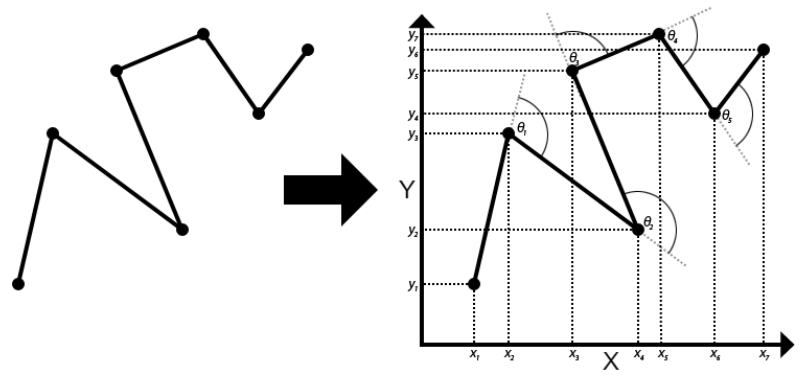

Slika 1: Preslikava verige v 2D prostor

prične s točko $O$ ("origin") in konča s točko $E$ ("endpoint"). Zaradi lažje predstavitve preselimo verigo v 2D kartezični prostor (slika 1), v katerem bomo predstavili nekatere lastnosti, ki pa veljajo tudi za 3D prostor.

$\mathrm{V} 2 \mathrm{D}$ kartezičnem prostoru se tako prva točka $O\left(x_{0}, y_{0}\right)$, zmeraj nahaja na znanih in nespremenljivih koordinatah. Ponavadi je to kar koordinatno izhodišče. Koordinate vsake naslednje točke $\left(x_{i}, y_{i}\right)$ pa lahko izračunamo iz koordinat prejšnje točke in naslednjih dveh parametrov:

- dolžine povezave - $d_{i}$, med sosednjima točkama in

$$
d_{i}=d\left(\left(x_{i}, y_{i}\right),\left(x_{i+1}, y_{i+1}\right)\right) ; \quad 0 \leq i<n
$$

- kotom - $\theta_{i}$, ki ga ta povezava določa.

$$
\theta_{i}=\theta\left(\left(x_{i}, y_{i}\right),\left(x_{i+1}, y_{i+1}\right)\right) ; \quad 0 \leq i<n
$$

V nadaljevanju bomo celotno verigo zaradi lažjega prehoda na rešitev imenovali roka, vsaki točki pa bomo rekli sklep - $S$. Posamezen sklep $\mathbf{S}_{i}$ bo tako definiran kot vektor komponent:

$$
\mathbf{S}_{i}=\left\{d_{i}, \theta_{i}\right\} ; \quad 0 \leq i<n-1
$$

Vidimo, da zgornja enačba ne vsebuje končnega sklepa $E$. Razlog je v tem, da slednji nima naslednika, zatorej ni kota in razdalje, za katera bi bil naslednji sklep bodisi obrnjen ali oddaljen od $E$.

Predstavimo še dva navidez podobna, vendar povsem različna problema. Vsak izmed njiju namreč rešuje svojo specifično nalogo, glede na znane podatke. 
- Direktna kinematika ("Forward Kinematics") - FK: opisuje matematični proces računanja koordinat končnega sklepa $E$ iz parametrov vseh predhodnih sklepov [?].

- Inverzna kinematika ("Inverse Kinematics") - IK: opisuje matematični proces določanja parametrov vseh sklepov, da se bo končni sklep $E$ nahajal na željenih koordinatah [?].

Reševanje FK je trivialno in obsega zgolj geometrično računanje, medtem ko IK povzroča veliko večje probleme. Rešitev problema IK se namreč nahaja $\mathrm{v}$ kompleksnih, tesno povezanih in skrajno nelinearnih matematičnih enačbah, ki vračajo več različnih rešitev [?, ?]. Zato ne preseneča, da je tema najrazličnejših metod in raziskav. Za mnoge probleme IK obstajajo ti. analitične rešitve, ki so na voljo v zaprti obliki. Parametri, ki jih vračajo te rešitve, so točni in se izračunajo v zgolj nekaj mikrosekundah [?]. Vendar analitične rešitve bodisi še niso odkrite za vse probleme ali pa jih sploh ni mogoče pridobiti. V teh primerih se uporabijo ti. računske metode, katere pa vračajo zgolj približno rešitev in so ponavadi računsko, in posledično tudi časovno dokaj zahtevne. Nekatere izmed teh metod so [?]: Jacobian inversion method, Jacobian construction, iterativna metoda, optimizacijska metoda, Cyclic coordinate descent, Jacobian transpose method, genetsko programiranje, itd.

\section{DIFERENCIALNA EVOLUCIJA}

Algoritem diferencialne evolucije (DE) predstavlja metodo za globalno optimizacijo danega problema [?, ?]. Leta 1996 ga je predstavil K. Price kot eno izmed možnih metod za reševanje polinomov Čebišova. Še istega leta je algoritem dosegel zavidljive rezultate na prvem tekmovanju evolucijskih algoritmov v Nagoyi. Zaradi učinkovitosti in preprostosti je bil uporabljen za reševanje različnih probemov kot so npr. uglaševanje šahovske ocenitvene funkcije [?], optimizacijacija zvijanja proteinov [?], multimodalno optimizacijo [?] itd. Nekatere prednosti DE so, da je izjemno stabilen pri problemih, ki vključujejo nekonveksne, multimodalne in nelinearne funkcije. Torej je nalašč primeren za naš problem, kjer rešujemo IK.

Način delovanja diferencialne evolucije prikazuje slika 2 in vsebuje naslednje mehanizme:

1. Definiranje začetne populacije - naključno definiramo $N p$ število posameznikov - $\mathbf{X}_{i}^{G}$ (imenovanih tudi starševski vektorji), kjer vsak posameznik predstavlja morebitno rešitev obravnavanega problema:

$\mathbf{X}_{i}^{G}=\left\{x_{0}, x_{1}, \ldots, x_{j}\right\} ; 0 \leq i<N p, 0 \leq j<D, G=0$,

- $x_{j}$ - j-ta neznanka v problemu

- $N p$ - število posameznikov znotraj populacije

- $D$ - dimenzija problema

- $G$ - generacija

2. Sprehod skozi vse generacije - v vsaki iteraciji DE se izvede ena generacija $(G)$, vse dokler ni zadoščeno zaustavitvenemu kriteriju, kot sta npr.: maksimalno število ovrednotenj in doseganje določene kvalitete rešitve.
1.

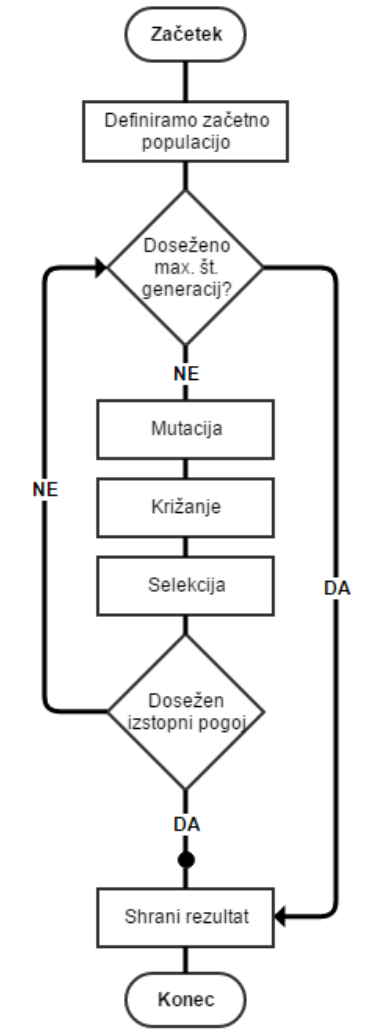

Slika 2: Potek algoritma diferencialne evolucije.

3. Mutacija - iz starševskih vektorjev $\left(\mathbf{X}_{i}^{G}\right)$ ustvarimo ti. mutiran vektor $\left(\mathbf{M}_{i}^{G}\right)$.

$$
\begin{aligned}
\mathbf{M}_{i}^{G} & =\mathbf{X}_{\mathbf{r}_{1}^{i}}^{G}+F *\left(\mathbf{X}_{\mathbf{r}_{2}^{i}}^{G}-\mathbf{X}_{\mathbf{r}_{3}^{i}}^{G}\right) \\
0 & \leq i<N p, \quad r_{0}^{i} \neq r_{1}^{i} \neq r_{2}^{i} \neq i
\end{aligned}
$$

- $\mathbf{X}_{r_{k}^{i}}^{G}$ - naključni starševski vektor; $k=\{1,2,3\}$

- $F$ - mutacijski faktor

4. Križanje - definira postopek, v katerem iz starševskih in mutiranih vektorjev sestavimo preizkusni vektor $\left(\mathbf{P}_{i}^{G}\right)$ :

$$
\mathbf{P}_{i, j}^{G}= \begin{cases}\mathbf{M}_{i, j}^{G}, & \text { če je } \operatorname{Rand}_{i, j}[0,1) \leq C r \\ \mathbf{X}_{i, j}^{G}, & \text { drugače }\end{cases}
$$

- $C r$ - faktor križanja

5. Selekcija - vsak $i$-ti preizkusni in pripadajoči starševski vektor ocenimo s pomočjo ocenitvene funkcije (eval). V kolikor je ocena za preizkusni vektor boljši od ocene za starševski vektor, potem preizkusni vektor zamenja starševski vektor $\mathrm{v}$ populaciji, kot prikazuje naslednja enačba:

$$
\mathbf{X}_{i}^{G+1}= \begin{cases}\mathbf{P}_{i}^{G}, & \text { če je } \operatorname{eval}\left(\mathbf{P}_{i}^{G}\right) \geq \operatorname{eval}\left(\mathbf{X}_{i}^{G}\right) \\ \mathbf{X}_{i}^{G}, & \text { drugače }\end{cases}
$$




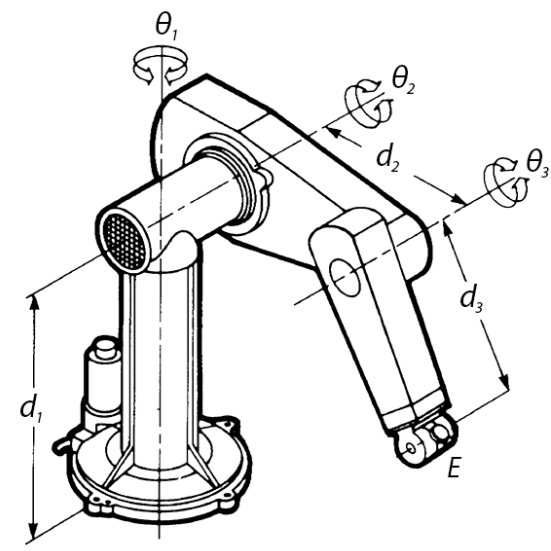

Slika 3: Puma 560 s parametri [?].

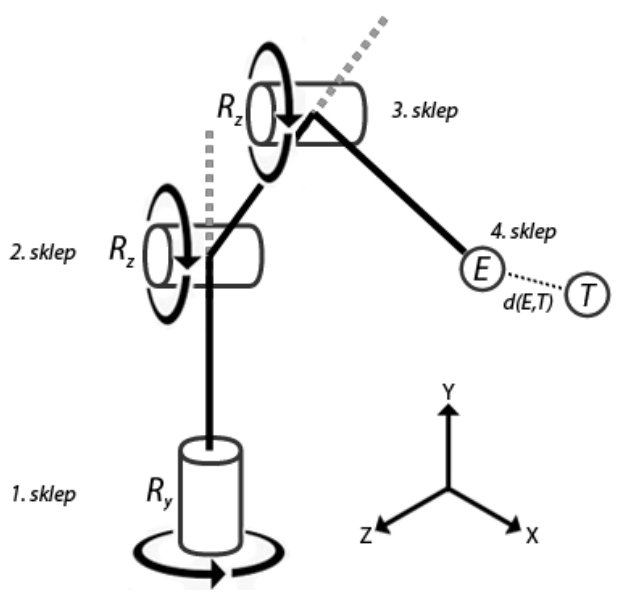

Slika 4: Skelet PUME 560.
6. Doseganje izstopnega pogoja - evolucijski proces algoritma DE se zaključi, ko obvelja kateri izmed naštetih pogojev:

- doseženo maksimalno število ovrednotenj posameznikov,

- preseženo časovno obdobje,

- najboljša rešitev v populaciji že določeno število generacij ostaja ista - algoritem je obstal v minimumu / maksimumu in

- najboljša rešitev je enaka ali boljša od pričakovane.

7. Rezultati DE - rezultat je posameznik, ki je dosegel najboljši rezultat glede na ocenitveno funkcijo (eval).

\section{REŠITEV}

Problem IK zasledimo na mnogih področjih, a na nobenem drugem področju ne pride tako do izraza kot $\mathrm{v}$ robotiki. Iz tega razloga bomo predlagano rešitev predstavili na problemu IK robotske roke PUMA 560 (Programmable Universal Machine for Assembly).

Roka obsega vsega 7 sklepov, kjer je prvih 6 sklepov nastavljivih, zadnji pa predstavlja končno točko IK - E. Ker so povezave pri PUMA 560 fiksnih dolžin $\left(d_{\min , i}=d_{\max , i} ; i=\right.$ $\{0-6\}$ ), to pomeni, da ima vsak sklep nastavljiv samo parameter $\theta_{i}$. Pri 6 nastavljivih sklepih je PUMA 560 omejena s 6 DOF (Degree Of Freedom - število neodvisnih parametrov robotske roke, s katerimi jo lahko manipuliramo).

$\mathrm{V}$ našem primeru se bomo omejili na prve 3 sklepe iz naslednjih razlogov:

- prvi trije sklepi opravijo večino pozicioniranja in

- glava roke je rotacijska in vsebuje preostale sklepe, ki pa so analitično rešljivi.

Vse 3 sklepe iz glave robotske roke bomo združili v končni četrti sklep $E$ (slika 3 ). Koordinate sklepa $E$ bodo tiste, ki
Tabela 1: Omejitve za prve 3 sklepe PUMA 560 [?].

\begin{tabular}{|l||l|l|l|l|l|}
\hline sklep & $\boldsymbol{\theta}_{\min , i}\left({ }^{\circ}\right)$ & $\boldsymbol{\theta}_{\max , i}\left({ }^{\circ}\right)$ & $\mathbf{d}_{\min , i}(\mathrm{~mm})$ & $\mathbf{d}_{\max , i}(\mathrm{~mm})$ & $\mathrm{os}(R)$ \\
\hline 1 & -160 & 160 & 672 & 672 & $\mathbf{R}_{y}$ \\
2 & -180 & 70 & 432 & 432 & $\mathbf{R}_{z}$ \\
3 & -45 & 220 & 433 & 433 & $\mathbf{R}_{z}$ \\
\hline
\end{tabular}

nas bodo v nadaljevanju tudi zanimale, saj bomo skušali ta sklep s pomočjo algoritma DE čim bolj približati poljubni točki v prostoru ( $T$ - target $)$.

Preselimo sedaj problem IK PUME 560 v 3D kartezični prostor. Kot smo že omenili, bomo rešitev IK dobili tako, da bomo minimizirali razdaljo med sklepom $E$ in točko $T$ (slika 4). To bomo dosegli z računanjem razdalje med dvema točkama oz. uporabo naslednje ocenitvene funkcije:

$$
\text { eval }=d(E, T)=\sqrt{\sum_{i=0}^{n}\left(x_{i}-y_{i}\right)^{2}} ; n<3 .
$$

Kot vse robotske roke, ima tudi PUMA 560 nekatere omejitve (glej tabelo 1). Poleg dolžin povezav, so tu tudi omejitve pri rotaciji. Posamezen sklep lahko namreč zavzame poljuben kot z intervala $\left[\theta_{\min , i}, \theta_{\max , i}\right]$ okrog določene osi.

Iz omejitev (tabela 1) definiramo začetno populacijo algoritma DE. Vsak njen posameznik, $\mathbf{X}_{i}$, je vektor $\mathrm{z}$ enako dimenzijo, kot je DOF obravnavanega problema. $\mathrm{V}$ našem primeru, kjer imamo 3DOF problem, imamo tako posameznike z $D=3$. Posamezna komponenta posameznika predstavlja kot $\theta_{i} j$-tega sklepa $\left(\mathbf{X}_{i, j}^{0}=\theta_{j}\right)$.

Vsak posameznik tako predstavlja morebitno rešitev problema, saj vsebuje vse parametre, s katerimi upravljamo z robotsko roko. Pri mutaciji moramo paziti, da s katero od komponent, (v našem primeru $\theta_{j}$ ) ne zapustimo predefiniranega intervala. V kolikor bi kršili omejitve, bi jih lahko kršila tudi končna rešitev in bi bila nedopustna. Vsakič, ko kličemo ocenitveno funkcijo v koraku selekcije, moramo najprej iz parametrov posameznega vektorja izračunati FK. Šele ko poznamo rezultat $\mathrm{FK}$, torej koordinate točke $E$, lahko iz- 
Tabela 2: Uporabljene konstante pri meritvah.

\begin{tabular}{l|l} 
Konstanta & Vrednost \\
\hline robot & PUMA 560 \\
št. zagonov & 100 \\
$F$ & 0,5 \\
$C r$ & 0,9 \\
$\epsilon$ & $1 \mathrm{~mm}$ \\
maksimalno število ovrednotenj & 100.000 \\
časovna omejitev & -
\end{tabular}

\begin{tabular}{|c|c|c|c|c|}
\hline \multicolumn{2}{|c|}{ Cabela } & \multicolumn{3}{|c|}{$\begin{array}{l}\text { UMA } \\
\text { Uspešnost }\end{array}$} \\
\hline \# & & 10 & 100 & 3 \\
\hline 1 & $\{350,00 ; 350,00 ; 350,00\}$ & 23 & 98 & 100 \\
\hline 2 & $\{250,30 ; 420$, & 11 & 100 & 100 \\
\hline 3 & $\{-315,60 ; 430,20$ & 23 & 100 & 100 \\
\hline 4 & $; 601,2$ & 34 & 100 & 100 \\
\hline$=$ & $\{301,40 ; 720,10 ;-400,60\}$ & 42 & 100 & 100 \\
\hline o & 903,8 & 32 & 100 & 100 \\
\hline 7 & $\{202,80 ; 1000,00 ; 712,67\}$ & 38 & 100 & 100 \\
\hline r & $\{-385,20 ; 170,3$ & 32 & 100 & 100 \\
\hline 9 & $\{-537$ & 33 & 100 & 100 \\
\hline 10 & $\{-754,34 ; 734,67 ; 734,14\}$ & 0 & 0 & 0 \\
\hline
\end{tabular}

Tabela 4: Podrobnejši rezultati za točko 6.

\begin{tabular}{c|cc|cc|}
\multirow{2}{*}{$N p$} & \multicolumn{2}{|c|}{ Povprečje } & \multicolumn{2}{c}{ Najboljši posameznik } \\
\cline { 2 - 5 } & čas (s) & napaka (mm) & čas (s) & napaka (mm) \\
\hline 100 & 0,42 & 0,74 & 0,39 & 0,28 \\
300 & 2,28 & 0,74 & 0,74 & 0,30
\end{tabular}

računamo evklidsko razdaljo. Algoritem DE bo tako skozi generacije optimiziral parametre posameznikov v populaciji, dokler ne bo našel rešitve IK ali pa bo dosegel katerega od izstopnih pogojev. Rešitev za IK je najdena, kadar je evklidska razdalja med $E$ in $T$ manjša od tiste, ki smo jo predpisali: $E-T<\epsilon$

\section{EKSPERIMENTI}

Eksperiment smo izvajali s pomočjo algoritma DE in nastavitev, ki so prikazane v tabeli 2 . Tabela 3 prikazuje dobljene rezultate eksperimenta. Za vsako točko in tri različne vrednostih $N p=\{10,100,300\}$ smo izvedli 100 neodvisnih zagonov. Uspešnost predstavlja odstotek, koliko zagonov izmed 100-ih je našlo rešitev IK. Vidimo, da za zadnjo točko algoritem ni našel rešitev. Razlog temu je ciljna točka, ki je izven dosega robota. Možno je tudi, da algoritem za isti problem pri drugačnem semenu najde različno rešitev, ki pa je lahko prav tako pravilna (dopustna).

V tabeli 4 so podrobneje predstavljeni rezultati za točko 6 , kjer je algoritem v obeh primerih za $N p=100$ in $N p=300$ dosegel $100 \%$ uspešnost. Iz tabele vidimo, da se v prvem primeru algoritem konča več kot petkrat hitreje in s skoraj štiri krat manj klici ocenitvene funkcije. Iz tega lahko sklepamo, da je $N p=100$ veliko boljša izbira za velikost populacije. Vendar moramo biti pazljivi, saj ni nujno, da bo rešitev zmeraj najdena (kar vidimo na primeru točke 1 ). V primeru majhne populacije $N p=10$, pa se algoritem ni izkazal, saj zgolj z 10 posamezniki ni zmožen v celoti raziskati iskalnega prostora in se je verjetno ujel $\mathrm{v}$ lokalnem optimumu.

\section{ZAKLJUČEK}

Kot je razvidno iz rezultatov, algoritem uspešno najde rešitev za vsako podano točko (seveda za tiste, pri katerih je IK rešljiva). Uspešnost algoritma se povečuje z večanjem velikosti populacije, vendar moramo paziti, saj se obenem poveča tudi čas, ki je potreben, da to rešitev dosežemo. Algoritem je nastavljiv in lahko sprejme različne nastavitve različnih robotskih rok (poljubno število DOF), tudi takšnih, kjer dolžine povezav niso fiksne. Vendar z bolj kompleksnimi robotskimi rokami ali nasplošno s problemi IK moramo ponovno najti ustrezne nastavitve algoritma.

\section{Zahvala}

Janez Brest in Borko Bošković priznavata financiranje prispevka s strani Javne agencije za raziskovalno dejavnost Republike Slovenije, raziskovalni program P2-0041 - Računalniški sistemi, metodologije in inteligentne storitve.

\section{LITERATURA}

[1] Ikfast: The robot kinematics compiler. http://openrave.org/docs/. 29.8.2017.

[2] Inverse kinematics - basic methods. http://old.cescg.org/CESCG-2002/LBarinka/. 29.8.2017.

[3] B. Bošković and J. Brest. Differential evolution for protein folding optimization based on a three-dimensional AB off-lattice model. Journal of Molecular Modeling, 22:1-15, 2016.

[4] B. Bošković and J. Brest. Clustering and Differential Evolution for Multimodal Optimization. In 2017 IEEE Congress on Evolutionary Computation, pages 698-705, 2017.

[5] B. Bošković, J. Brest, A. Zamuda, S. Greiner, and V. Žumer. History Mechanism Supported Differential Evolution for Chess Evaluation Function Tuning. Soft Computing - A Fusion of Foundations, Methodologies and Applications, 15:667-682, 2011.

[6] J. Craig. Introduction to Robotics: Mechanics and Control. Addison-Wesley series in electrical and computer engineering: control engineering. Pearson/Prentice Hall, 2005.

[7] G. Pampara, A. P. Engelbrecht, and N. Franken. Binary differential evolution. In 2006 IEEE International Conference on Evolutionary Computation, pages 1873-1879, 2006.

[8] R. Paul. Robot Manipulators: Mathematics, Programming, and Control : the Computer Control of Robot Manipulators. Artificial Intelligence Series. MIT Press, 1981.

[9] J. Rutherford. Using the puma560 robot;a user's guide to basic operation of the puma arm robot, 2012.

[10] R. Storn and K. Price. Differential evolution - a simple and efficient heuristic for global optimization over continuous spaces. Journal of Global Optimization, 11(4):341-359, Dec 1997.

[11] F. Zhongtao, W. Yang, and Z. Yang. Solution of inverse kinematics for $6 \mathrm{r}$ robot manipulators with offset wrist based on geometric algebra. 5:310081-310087, 082013. 